Editorial

\title{
Waste Strategies Development in the Framework of Circular Economy
}

\author{
Antonis A. Zorpas ${ }^{1}\left(\right.$ D), Maria K. Doula ${ }^{2}$ (D) and Mejdi Jeguirim ${ }^{3,4, *(D)}$ \\ 1 Lab of Chemical Engineering and Engineering Sustainability, Faculty of Pure and Applied Sciences, \\ Open University of Cyprus, Giannou Kranidioti 33, Nicosia 2220, Cyprus; \\ antoniszorpas@yahoo.com or antonis.zorpas@ouc.ac.cy \\ 2 Laboratory of Non-Parasitic Diseases, Benaki Phytopathological Institute, 8 Stef. Delta St., Kifissia, \\ 14561 Athens, Greece; mdoula@otenet.gr \\ 3 Institut de Science des Matériaux de Mulhouse, CNRS UMR 7361, Université de Haute-Alsace, \\ F-68100 Mulhouse, France \\ 4 Université de Strasbourg, F-67081 Strasbourg, France \\ * Correspondence: mejdi.jeguirim@uha.fr
}

check for updates

Citation: Zorpas, A.A.; Doula, M.K.; Jeguirim, M. Waste Strategies Development in the Framework of Circular Economy. Sustainability 2021, 13, 13467. https://doi.org/10.3390/ su132313467

Received: 1 December 2021

Accepted: 4 December 2021

Published: 6 December 2021

Publisher's Note: MDPI stays neutral with regard to jurisdictional claims in published maps and institutional affiliations.

Copyright: (C) 2021 by the authors. Licensee MDPI, Basel, Switzerland. This article is an open access article distributed under the terms and conditions of the Creative Commons Attribution (CC BY) license (https:/ / creativecommons.org/licenses/by/ $4.0 /)$.

\section{Introduction}

Current studies proposed that more that $2 \mathrm{bn}$ tons of solid waste/year are produced globally [1-3]. Waste, in its general definition (solid and/or liquid), is among the most challenging environmental concerns in many communities. Considering the goals that are raised in the context of the circular economy (which focuses on the recycling of at least $65 \%$ of communal waste by 2035 , and up to $70 \%$ by 2030 , according to the common EU target), several strategies are needed. To propose any answer to waste management, strategies related to the hierocracy, as mentioned in the waste framework directive (WFD), must be developed. This special issue invited submissions connected to strategy development at the horizontal level, i.e., solid waste, wastewater, agri-waste, etc. [1-21].

The responses to our invitation had the following statistics:

- $\quad$ Submissions (16);

- Publications (14);

- Rejections (2);

- $\quad$ Article types: research article (13), review article (1)

The authors' geographical distribution (published papers) is:

- $\quad$ Cyprus (3)

- $\quad$ Greece (2)

- Kazakhstan (2)

- Australia (1)

- China (1)

- Oman (1)

- $\quad$ Palestine (1)

- $\quad$ Spain (1)

- $\quad$ Tunisia (1)

- $\quad$ United Kingdom (1)

The published submissions, without limitation, are related to waste strategies management, air pollution, waste valorization, environmental impact evaluation, life cycle analysis and wastewater treatment.

\section{Short Review of the Contributions in This Issue}

Although waste will continue to grow, and despite several efforts to reduce waste in many levels, there is a total absence of a holistic approach at the political level to solve the crisis of waste management in depth. In fact, since the treaty of Rome, back in 1957, there 
was no common statement from the leaders to take action on environmental protection. For more than 60 years, there were no specific initiatives at the European level. A strategic approach is needed and is essential to solve the problem [1-21].

Ciu et al. [4] presented the subject-object-process model, within the waste classification management system, and proposed a model focused on municipal solid waste (MSW), which also uses several KPIs (Key Performed Indicators)—considering Beijing, China, as an example, and the citizens' behaviors in several household waste management systems (WMS). The proposed research indicates that in the existing WMS the interaction between government management and residents' domestic waste classification behavior varies from 0.40 to 0.68 , compared with the behavior between companies and residents, which varies from 0.45 to 0.75 . Social behavior is considered a vital issue in any waste strategy plan, as through the analysis of the social attitude and behavior of the participants several weaknesses have been defined in order to improve the existing management system and the appropriate strategy.

Food waste prevention is on the top of the stakeholders' priority list at the global level $[5,6]$. Several studies mentioned that the households are the main food waste producers. Among the main issues concerning food waste and the predictability of consumers' behavior, Kritikou et al. try to analyse, in their last report, the main factors that affect food waste generation in Greece [7]. The authors have used 921 households from Greece based on a structured questionnaire considering all ethical issues. Using the Theory of Planned Behavior, they examined the relations between the attitude to food waste, subjective norms, perceived behavior at intention, control, and self-reported behavior, considering the knowledge on prevention control in general. The proposed research indicates that the food waste prevention was mainly determined by a general environmental attitude. This has a direct effect on environmental education and food waste prevention behavior. Furthermore, the results of the proposed study can act as a reference point for policy makers and the implantation of a campaign focused on food waste prevention.

Conventional policies and practices cannot be resolved during the COVID-19 pandemic. Furthermore, COVID-19 has a direct impact on many industrial activities, like construction and demolition (C\&D) waste management. More than that, Extended Producer Responsibility (EPR) may prevent waste development and promote a circular economy strategy, to be adopted in the construction industry. Shooshtarian et al. [8] reviewed the Australian regulatory environment and practice in order to distinguish barriers to implement a relative strategy on C\&D considering EPR. Using multiple selection criteria and 59 diverse causes, the presented results point out that there is an extensive support among diverse stakeholders to develop EPR and extend the existing regulation to other materials. The main obstacles remain the relevant cost and the time implications for the EPR policy. The result of this research could be useful for policy makers dealing with EPR policies.

In a strategic approach to help communities and local economies, the entire hospitality industry plays a fundamental role. At the same time, the entire hospitality industry led to opposing environmental effects, particularly in coastal regions which are documented as being of strategic importance. In addition, coastal areas are facing lots of pressure from the hospitality industry due to the massive amount of waste production. Loizia et al. [2] provided responses to the hypothesis that the COVID-19 pandemic lockdown scenario would advance the environmental performance in this area. Until now, there are very few studies focused on the environmental dimensions in any coastal area due to the pandemic. Using a number of KPIs, the environmental performance was measured considering the clean coast index (CCI), waste accumulation index (WAI) and waste accumulation rate (WAR), as well as through micro-, meso- and macroplastic concentrations on the beach. The proposed research could serve as a reference point for competent authorities in order to reorganize their waste management plan, by expanding their waste infrastructures to defend the coastal environment.

Air quality is considered a vital indicator for human health. The World Health Organization pointed out that, on a yearly basis, approximately 7-9 million citizens are 
dying due to air pollution issues. In general, air pollution is strictly related to energy production, climate change and human health. Especially in modern cities, air pollution plays a fundamental role in human health, and especially the concentration of PM10, PM2.5 and PM1 $\mu \mathrm{m}$. The PM concentrations were measured in the city of Limassol in Cyprus from natural (e.g., dust events) and anthropogenic (i.e., traffic, cement works, restaurants) activities in two seasons: summer and spring [9]. The results were useful to monitor the air quality in cities.

A Life Cycle Analysis (LCA) is an environmental tool that is very useful to assess any strategy put in place [10-12]. Litskas et al. [10], using an LCA approach, assess grapes' environmental footprint (EF). Using data from three several production systems from wineries in Cyprus and the database from AGRIBALYSE (life cycle inventory-LCI data), they calculate the EF of the vineyards through the Open LCA software. The system boundaries were chosen from "cradle to winery door", and 1 ton of grapes carried to the winery was chosen as the functional unit. Machinery, oil and sulfur production were recognized as EF hotspots for organic grapes, while the production of fertilizer was recognized as the EF hotspot for high-input grape manufacture. This research points out that future studies need to enrich the LCI databases.

Considering the effectiveness of wastewater treatment technologies on real conditions is vital for the effective monitoring of wastewater [13]. Poultry slaughterhouse wastewater generated from defeathering, cooling and evisceration processes was preserved using a electrochemical method with Fe-Gr, Fe-Fe and Al-Gr electrode groupings [14]. In addition, water and sanitation is considered as one of the main SDGs-more specifically, the SDG 6 . There are many studies focusing on the competence of the wastewater treatment. For this special issue, Meiramkulova et al. $[15,16]$ examined the effect of wastewater behavior in a poultry slaughterhouse. The proposed systems include membrane filtration, electrolysis and ultraviolet irradiation. The study took place in a poultry farm slaughterhouse in Kazakhstan. The water quality index (WQI) was used to provide answers on the quality of the drinking water that were used as a reference point. The engineering plants exposed a high purification productivity for most of the parameters.

Jellali et al. [17] assessed the environmental, technical and economic viability of the anaerobic digestion (AD) sludge formed in a wastewater treatment plant (WWTP). Based on the characterization of the sludge samples, it was mentioned that for a 20-year project the production of electricity through $\mathrm{AD}$ was $43.9 \mathrm{GWh}$, while at the same time the reduction of greenhouse gas (GHG) emissions was greater than 37,000 ton. equivalent $\mathrm{CO}_{2}$.

Hindiyeh et al. [17] proposed a valuable explanation for avoiding the predicted Sea Level Rise (SLR) by the seawater desalination and storage within the des-plants distributed globally, which in a strategic approach is considered as a very promising scenario.

The agri-sector plays an important part concerning the food safety and scarcity. In addition, the agri-sector contributes to air quality contamination and the associated effects on the human health, and produces huge numbers of several waste types [12]. Olive mill wastes received huge attention due to the high waste volumes, mainly due to their toxicity and their negative impacts on the environment $[19,20]$. The oil extraction process produces huge seasonal quantities of olive by-products that require noteworthy attention because of their high organic content and significant toxicity due to the phenolic substances with extremely vital environmental issues [21-25]. A promising strategic approach beside composting $[21,22]$ is the thermal conversion of olive mill solid wastes and olive mill wastewaters into a rich nutrient biochar.

Author Contributions: The authors contributed equally to the manuscript. All authors have read and agreed to the published version of the manuscript.

Funding: This research received no external funding.

Institutional Review Board Statement: Not applicable. 
Informed Consent Statement: Not applicable.

Data Availability Statement: Not applicable.

Conflicts of Interest: The authors declare no conflict of interest.

\section{References}

1. Kazamias, G.; Zorpas, A.A. Cutting drilling waste from oil \& gas exploitation management through end-of-waste criteria in the framework of circular economy strategy. J. Clean. Prod. 2021, 322, 129098. [CrossRef]

2. Loizia, P.; Voukkali, I.; Chatziparaskeva, G.; Navarro-Pedreño, J.; Zorpas, A.A. Measuring the Level of Environmental Performance on Coastal Environment before and during the COVID-19 Pandemic: A Case Study from Cyprus. Sustainability 2021, 13, 2485. [CrossRef]

3. Voukkali, I.; Zorpas, A.A. Evaluation of Urban Metabolism assessment methods through SWOT Analysis and Analytical Hierocracy Process. Sci. Total Environ. 2022, 807, 150700. [CrossRef]

4. Cui, T.; Su, X.; Zhang, Y. Study on Compulsory Classification Management and Behavior Synergy of Municipal Solid Waste. Sustainability 2021, 13, 6265. [CrossRef]

5. Zorpas, A.A.; Voukkali, I.; Loizia, P. A prevention strategy plan concerning the waste framework directive in Cyprus. Fresenius Environ. Bull. 2017, 26, 1310-1317.

6. Zorpas, A.A.; Lasaridi, K.; Abeliotis, K.; Voukkali, I.; Loizia, P.; Fitiri, L.; Chroni, C.; Bikaki, N. Waste prevention campaign regarding the Waste Framework Directive. Fresenius Environ. Bull. 2014, 23, 2876-2883.

7. Kritikou, T.; Panagiotakos, D.; Abeliotis, K.; Lasaridi, K. Investigating the Determinants of Greek Households Food Waste Prevention Behaviour. Sustainability 2021, 13, 11451. [CrossRef]

8. Shooshtarian, S.; Maqsood, T.; Wong, P.S.; Khalfan, M.; Yang, R.J. Extended Producer Responsibility in the Australian Construction Industry. Sustainability 2021, 13, 620. [CrossRef]

9. Petsas, C.; Stylianou, M.; Zorpas, A.; Agapiou, A. Measurements of Local Sources of Particulates with a Portable Monitor along the Coast of an Insular City. Sustainability 2021, 13, 261. [CrossRef]

10. Litskas, V.; Mandoulaki, A.; Vogiatzakis, I.N.; Tzortzakis, N.; Stavrinides, M. Sustainable Viticulture: First Determination of the Environmental Footprint of Grapes. Sustainability 2020, 12, 8812. [CrossRef]

11. Banti, D.C.; Tsangas, M.; Samaras, P.; Zorpas, A. LCA of a membrane bioreactor compared to activated sludge system for municipal wastewater treatment. Membranes 2020, 10, 421. [CrossRef]

12. Tsangas, M.; Gavriel, I.; Doula, M.; Xeni, F.; Zorpas, A.A. Life cycle analysis in the framework of agricultural strategic development planning in the Balkan region. Sustainability 2020, 12, 1813. [CrossRef]

13. Nikologianni, A.; Betta, A.; Pianegonda, A.; Favargiotti, S.; Moore, K.; Grayson, N.; Morganti, E.; Berg, M.; Ternell, A.; Ciolli, M.; et al. New Integrated Approaches to Climate Emergency Landscape Strategies: The Case of Pan-European SATURN Project. Sustainability 2020, 12, 8419. [CrossRef]

14. Zorpas, A.A.; Coumi, C.; Drtil, M.; Voukkali, I. Municipal Sewage Sludge Characteristics and Waste Water Treatment Plant Effectiveness under Warm Climate conditions. Desalination Water Treat. 2011, 36, 319-333. [CrossRef]

15. Meiramkulova, K.; Jakupova, Z.; Orynbekov, D.; Tashenov, E.; Kydyrbekova, A.; Mkilima, T.; Inglezakis, V.J. Evaluation of Electrochemical Methods for Poultry Slaughterhouse Wastewater Treatment. Sustainability 2020, 12, 5110. [CrossRef]

16. Meiramkulova, K.; Zorpas, A.A.; Orynbekov, D.; Zhumagulov, M.; Saspugayeva, G.; Kydyrbekova, A.; Mkilima, T.; Inglezakis, V.J. The Effect of Scale on the Performance of an Integrated Poultry Slaughterhouse Wastewater Treatment Process. Sustainability 2020, 12, 4679. [CrossRef]

17. Jellali, S.; Charabi, Y.; Usman, M.; Al-Badi, A.; Jeguirim, M. Investigations on Biogas Recovery from Anaerobic Digestion of Raw Sludge and Its Mixture with Agri-Food Wastes: Application to the Largest Industrial Estate in Oman. Sustainability 2021, $13,3698$. [CrossRef]

18. Hindiyeh, M.; Albatayneh, A.; Altarawneh, R.; Jaradat, M.; Al-Omary, M.; Abdelal, Q.; Tayara, T.; Khalil, O.; Juaidi, A.; Abdallah, R.; et al. Sea Level Rise Mitigation by Global Sea Water Desalination Using Renewable-Energy-Powered Plants. Sustainability 2021, 13, 9552. [CrossRef]

19. Vlyssides, A.G.; Loizidou, M.; Zorpas, A.A. Characteristics of solid residues from olive oil processing as a bulking material for co-composting with industrial wastewater. J. Environ. Sci. Health Part A 1999, 34, 737-748. [CrossRef]

20. Doula, M.K.; Papadopoulos, A.; Kolovos, C.; Zorpas, A.A. Evaluation of the application of Olive Mill Waste on soils; The case study of disposal areas in Crete, Greece. Comptes Rendus Chim. 2020, 23, 705-720. [CrossRef]

21. Zorpas, A.A.; Costa, N.C. Combination of Fenton Oxidation and Composting for the treatment of the olive solid residue and the olive mile wastewater from the olive oil industry in Cyprus. Bioresour. Technol. 2020, 101, 7984-7987. [CrossRef] [PubMed]

22. Zorpas, A.A.; Inglezakis, J.V. Intergraded Applied Methodology for the Treatment of Heavy Polluted Waste waters from the olive oil industries. Appl. Environ. Soil Sci. 2011, 537814. [CrossRef]

23. Jeguirim, M.; Dutournié, P.; Zorpas, A.A.; Limousy, L. Olive mill wastewater: From a pollutant to green fuels, agricultural water source and bio-fertilizer-1. The drying kinetic. Energies 2017, 10, 1423. [CrossRef] 
24. Marks, E.A.N.; Kinigopoulou, V.; Akrout, H.; Azzaz, A.A.; Doulgeris, C.; Jellali, S.; Rad, C.; Sánchez Zulueta, P.; Tziritis, E.; El-Bassi, L.; et al. Potential for Production of Biochar-Based Fertilizers from Olive Mill Waste in Mediterranean Basin Countries: An Initial Assessment for Spain, Tunisia, and Greece. Sustainability 2020, 12, 6081. [CrossRef]

25. Hadroug, S.; Jellali, S.; Jeguirim, M.; Kwapinska, M.; Hamdi, H.; Leahy, J.J.; Kwapinski, W. Static and Dynamic Investigations on Leaching/Retention of Nutrients from Raw Poultry Manure Biochars and Amended Agricultural Soil. Sustainability 2021, 13, 1212. [CrossRef] 